\title{
CD147 Is a Promising Target of Tumor Progression and a Prognostic Biomarker
}

\author{
Alexandra Landras ${ }^{1}$, Coralie Reger de Moura ${ }^{1,2}$, Fanelie Jouenne ${ }^{1,2}$, Celeste Lebbe ${ }^{1,3}$, \\ Suzanne Menashi ${ }^{1,2}$ and Samia Mourah 1,2,* \\ 1 INSERM UMRS 976, Team 1, Human Immunology Pathophysiology \& Immunotherapy (HIPI), \\ University of Paris, 75010 Paris, France; alexandra.land@hotmail.fr (A.L.); coralie.reger@aphp.fr (C.R.d.M.); \\ fanelie.jouenne@aphp.fr (F.J.); celeste.lebbe@aphp.fr (C.L.); suzanne.menashi@gmail.com (S.M.) \\ 2 Pharmacogenomics Department, Assistance Publique-Hôpitaux de Paris (AP-HP), Saint Louis Hospital, \\ 75010 Paris, France \\ 3 Dermatology Department and Centre d'Investigation Clinique (CIC), \\ Assistance Publique-Hôpitaux de Paris (AP-HP), Saint Louis Hospital, 75010 Paris, France \\ * Correspondence: samia.mourah@aphp.fr; Tel.: +33-1-42-49-48-85
}

Received: 18 September 2019; Accepted: 13 November 2019; Published: 16 November 2019

\begin{abstract}
Microenvironment plays a crucial role in tumor development and progression. Cancer cells modulate the tumor microenvironment, which also contribute to resistance to therapy. Identifying biomarkers involved in tumorigenesis and cancer progression represents a great challenge for cancer diagnosis and therapeutic strategy development. CD147 is a glycoprotein involved in the regulation of the tumor microenvironment and cancer progression by several mechanisms-in particular, by the control of glycolysis and also by its well-known ability to induce proteinases leading to matrix degradation, tumor cell invasion, metastasis and angiogenesis. Accumulating evidence has demonstrated the role of CD147 expression in tumor progression and prognosis, suggesting it as a relevant tumor biomarker for cancer diagnosis and prognosis, as well as validating its potential as a promising therapeutic target in cancers.
\end{abstract}

Keywords: CD147; biomarker; tumor microenvironment; prognosis; targeted therapy

\section{Introduction}

Tumor complexity represents a challenge with regard to the development of new therapeutic strategies [1,2]. Tumor development is a dynamic process involving cooperation between different cellular and noncellular elements of the tumor microenvironment (TM) such as fibroblasts, endothelial cells, pericytes and immune cells including lymphocytes B and T, tumor-associated macrophages, natural killers, as well as extracellular components (growth factors, hormones, cytokines) surrounded by a blood/lymphatic vascular network present in a complex extracellular matrix (ECM). Recently, cancer progression and drug resistance have been proposed to result from the interaction of the tumor cells with their microenvironment $[3,4]$. Targeting molecules capable of modulating the TM in favor of the tumor cell can lead to efficient therapeutic strategies. In addition, the microenvironment, through the proteolytic degradation of its ECM, can further promote tumor progression and ease the metastasis process [5]. Matrix metalloproteinase (MMPs), which are the main ECM degrading enzymes, are often overexpressed in cancer and are associated with a poor prognosis [6]. Understanding the regulation of their production and activation appears to be important for the development of new therapeutic strategies.

CD147 (cluster of differentiation 147) is a glycoprotein initially known as a regulator of MMPs, through cell-matrix and cell-cell interaction and represents a potential target for cancer therapy [7]. 
CD147 was found to be overexpressed in cancer cells and is believed to promote their malignant proprieties, such as proliferation and inhibition of cancer cell apoptosis [8]. During the past decades, CD147 was implicated, in addition to its role as a regulator of MMPs, in several other functions due to its ability to regulate or to bind with different molecular partners and hence has the ability to modulate several cellular pathways [9]. In particular, through its association with certain monocarboxylate transporter (MCTs), CD147 was shown to act as a key metabolic regulator in cancer. In addition, CD147 was also shown to be implicated in the angiogenesis process via the regulation of vascular endothelial growth factor (VEGF) production in tumor and stromal cells [10].

Earlier detection of cancer can greatly increase the opportunity for successful treatment. Identify new prognostic biomarkers can be useful for cancer clinical and therapeutic management [11]. An increasing number of studies have shown CD147 as a promising biomarker for predicting prognosis in many cancers [12].

\section{CD147 Biological Functions in Cancer: Structure and Partners}

A glycoprotein belonging to the immunoglobulin family and enriched on the surface of various types of tumor and stromal cells, including epithelial cells and fibroblasts [13], CD147 was initially named TCSF (tumor cell-derived collagenase stimulatory factor) and renamed Extracellular Matrix MetalloPRoteinase INducer (EMMPRIN) based on its matrix metalloproteinase (MMP) inducer function [14]. Although increasing MMPs expression in tumor cells was initially established as the major protumoral function of CD147 [14], several subsequent studies had demonstrated that its tumor-promoting role implicates other mechanisms, of which the interaction of CD147 with MCTs, leading to increased aerobic glycolysis appears to represent a major role.

CD147 is coded by Basigin (BSG) gene located on chromosome 19p13.3 [15]. Four variants of CD147 has been encoded (Basigin 1, 2, 3 and 4) through an alternative promoter and splicing [16]. The retinal-specific CD147 (Basigin 1) containing three immunoglobulin domains [17] and isoforms Basigin 3 and 4 contain a single immunoglobulin domain [18]. The most abundant isoform and complete information is only available for Basigin 2, named CD147 in the present review. It is composed of a signal sequence of 21 amino acids, an extracellular domain of 184 amino acids with two immunoglobulin domains, a transmembrane domain of 24 amino acids, and a cytoplasmic domain of 39 amino acids [19]. Structurally, one monomer of CD147 is composed of two domains, D1 corresponding to N-terminal domain (residues 22-101) and a C-terminal domain called D2 (residues 107-205) (Figure 1). Crystal structure showed CD147 monomers can associate with each other, leading to dimer formation [20]. It was first shown that CD147 dimerization can occur in the same cell [21]. This homodimerization on the plasma membrane is in a cis-dependent manner [22]. CD147 can also interact with other cells through CD147/CD147 interaction in trans-dependent manner, which can induce intracellular signaling [23]. Moreover, a soluble form of CD147 was shown to be internalized through surface CD147 binding and enhance proliferation and migration [24]. This interaction can then induce cell surface expression of CD147 [24]. Dimerization of CD147 is crucial for MMPs induction and cell invasion in hepatocellular carcinoma though MAPK pathway [25].

Cancer-associated fibroblasts (CAFs) are the most abundant components of tumoral stroma and contribute to the malignant phenotype of cancers. In 2019, Aoki et al. demonstrated that CD147 can stimulate adjacent fibroblasts thought CD73 interaction, increasing the secretion of MMP-2 and promoting invasion and metastasis [26]. CD147 has been shown to be implicated in the transformation of normal fibroblasts to cancer-associated-fibroblast through cancer-stroma interaction and the induction of alpha smooth muscle actin ( $\alpha$-SMA) expression, a marker of CAFs, promoting epithelial-to-mesenchymal transition of breast cancer cells [27]. CD147 contains three asparagine (Asn) glycosylation sites in the extracellular region. The glycosylation level of CD147 is related to its different molecular weights, which have been described and classified as low and high glycosylated CD147 forms [22]. The glycosylation of CD147 was shown to be necessary for its function, since the unglycosylated forms of CD147 were not able to induce fibroblast's MMPs production [28]. 


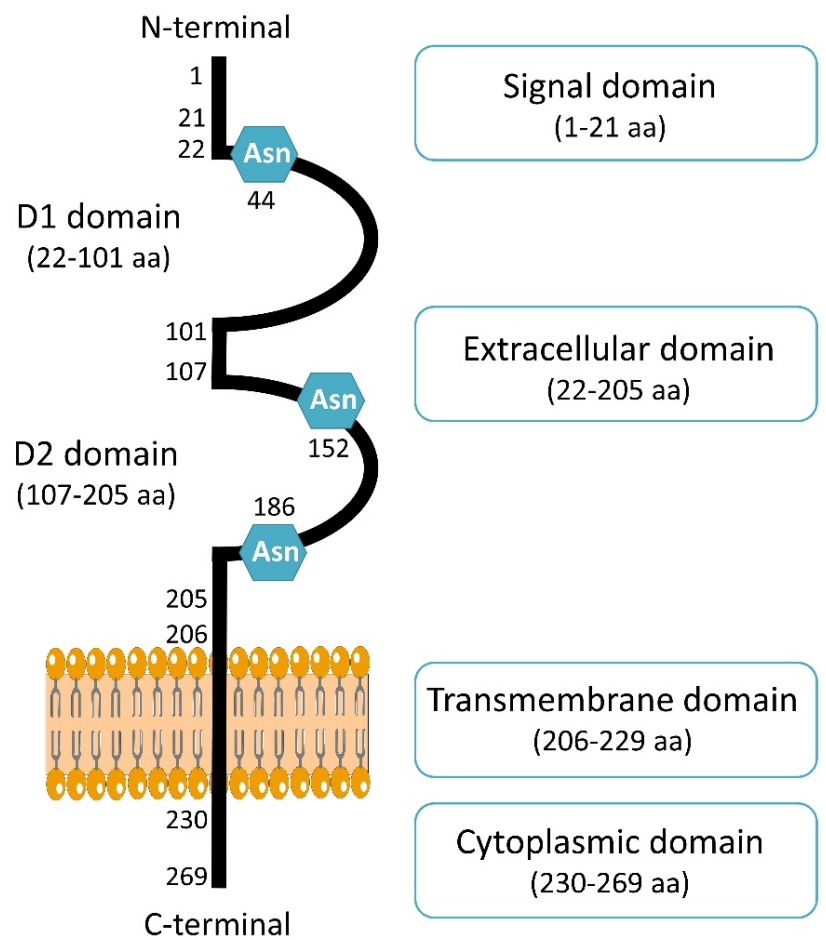

Figure 1. Schematic presentation of CD147 structure. CD147 consists of 269 amino acids (aa) and composed of a signal domain, an extracellular domain, a transmembrane domain and a cytoplasmic domain. CD147 contains three Asparagine (Asn) sites of glycosylation.

An important mechanism of action of CD147 is that it can be secreted by cells and released into the microenvironment. Two different ways by which the cell can generate these soluble forms of CD147 have been described; one involving an MT1-MMP-mediated cleavage of surface-bound CD147 [29] and a second is based on the release of microvesicules, containing full-length of CD147 molecules [30]. Recently, the interaction between ADAM12 and CD147 was shown to promote the cleavage of CD147 releasing its soluble form in the microenvironment, showing a new way to generate soluble CD147 [31]. A soluble form of CD147 was reported to be associated with tumor growth, metastasis formation and chemoresistance, and has been proposed as a clinical biomarker in breast cancer [32] and hepatocellular carcinoma [33].

CD147 is known to interact with numerous partners such as MCTs [34], caveolin-1 [35], CD98 and $\beta 1$ integrin [36] to promote cell metabolism, proliferation, migration and invasion [37].

A major protumoral action of CD147 was shown to involve a metabolic modification of the tumor microenvironment through its interaction with certain MCTs (MCT-1, MCT-4) that regulate tumor glycolysis via lactic acid export. By acting as a chaperone of MCTs, CD147 facilitates their cell membrane localization and functionality and increases tumor cell aerobic glycolysis, a hallmark of metastatic cancer [38,39]. Studies by Pouyssegur's group, who explored the role of CD147 in MMPs induction, furthermore suggested that the previously well-established MMPs induction function of CD147 only plays a minor role in cancer progression compared to that of CD147-MCT [40]. Grandja et al. showed by a direct interaction that CD147 can regulate MCTs expression and activity in non-small lung cancer. Indeed, CD147 knockout induced a decrease of the expression and the activity of MCT-1 and MCT-4 [41]. Glycolysis and cellular activities were found significantly inhibited after CD147 silencing with RNAi technology. A study in thyroid carcinoma cells showing a close association between CD147 and MCTs confirmed the dominant role of CD147 in glycolysis [42]. In multiple myeloma cells, CD147 was showed to act as a chaperone of MCT-1, thus promoting tumor growth within an acidic microenvironment [43]. These results reinforce the importance of the interaction between CD147 and MCTs as a major mechanism in tumor progression. 
Other cell surface partners of CD147 have been described. Caveolin-1 was shown to interact with CD147 and this had a negative effect on the MMP-inducing function of CD147 [44]. CD98 and CD147 form a complex with MCTs and play a critical role in the energy metabolism of the cell [45]. Cell motility was shown to be regulated by CD147/integrin interaction through FAK-STAT3 pathway [46]. CD147 overexpression also directly contributes to tumor angiogenesis by simulating VEGF production via the PI3K/AKT pathway [47].

The ABC transporter G2 (ABCG2) is known to be involved in drug resistance [48,49], thanks to its role in drug transport and efflux [50]. CD147 can regulate ABCG2 cellular location and dimerization [51], leading to cancer cell chemoresistance [52]. CD147 was also shown to be a signaling receptor for cyclophilin A (СурA), a cytosolic protein secreted in response to inflammatory stimulations. CypA is overexpressed in cancer and leads to malignant transformation and metastasis via ERK1/2 signaling [53]. CD147 interaction with CypA was shown to induce cancer cell proliferation [54] and regulates cell immunity and inflammation (Figure 2) [55].

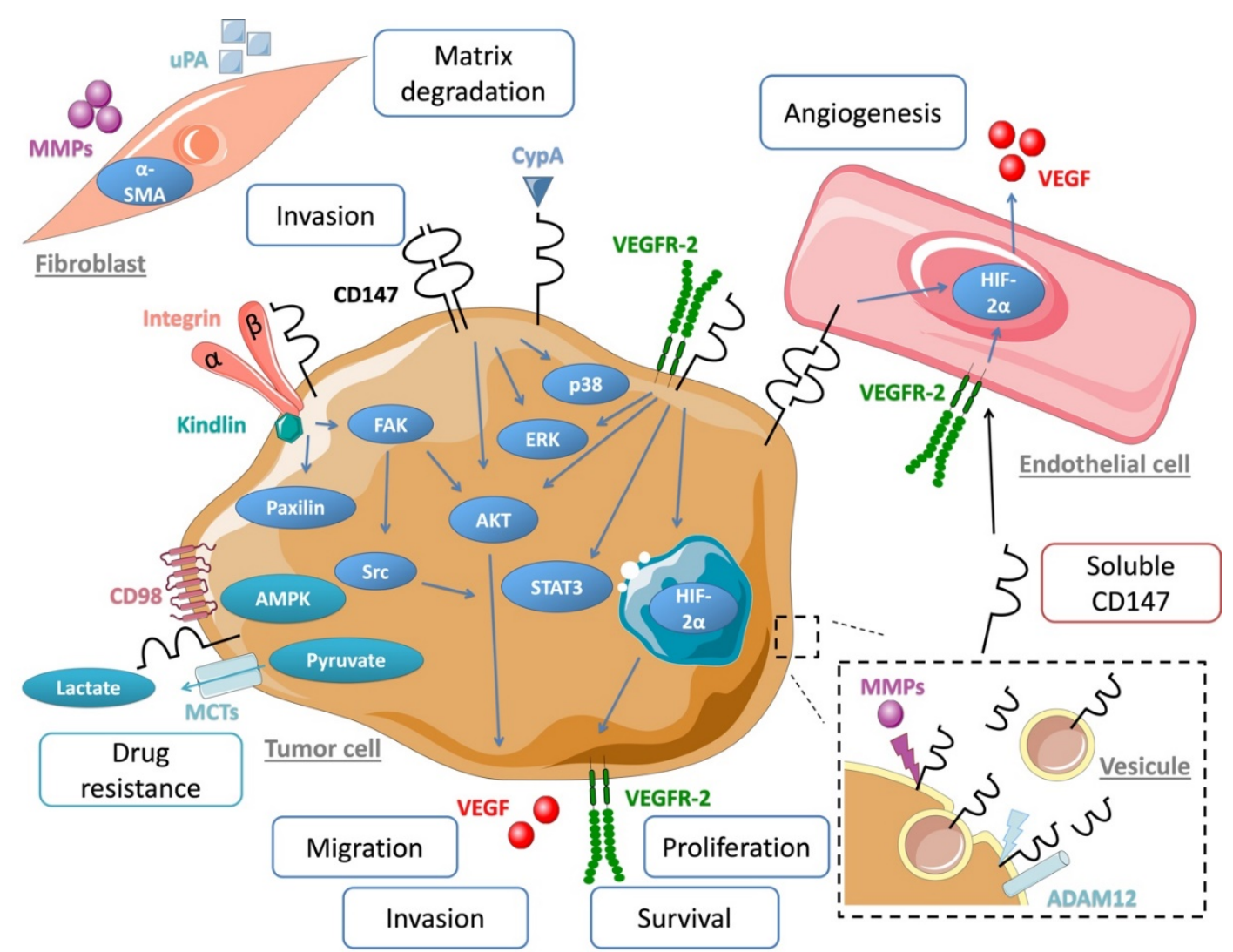

Figure 2. Schematic overview of CD147 associated partner, molecular pathway and microenvironment interaction involved in cancer progression.

\section{CD147 Regulates Cancer Cell Invasion and Metastasis}

Tumor invasion depends on a complex mechanism involving cell adhesion, migration and matrix degradation. In addition, the alteration in the surrounding microenvironment is known to further promote invasion by cooperating with the tumor cell and supporting its survival, proliferation and production of proteinases essential for degrading the extracellular matrix, mainly the MMPs and the serine proteases (uPA, plasmin). CD147 enriched on the surface of tumor cells, was shown to be an important factor in tumor stroma interactions, as it stimulates neighboring stromal to increase their synthesis of several MMPs [14,56]. The extracellular N-terminal region of CD147 was shown to be crucial for the MMPs induction [14,57]. Although MMPs induction may not represent the major tumor-promoting function as was previously thought, by degrading the surrounding stroma, MMPs 
are important in regulating cell growth, migration and invasion. CD147 was shown to stimulate the production of MMP-1, MMP-2, MMP-3 in melanoma [58] and MMP-9 in breast cancer [59] but had no effect on the specific tissue inhibitors of MMPs, TIMP-1 and TIMP-2 [60]. Following activation, MMP-9 lead to degradation of type IV collagen and promoted tumor cell invasion and metastasis in breast cancer [61]. CD147 and MMP-11 were overexpressed in colorectal cancer and showed a colocalization between both proteins. In addition to its role in invasion and metastasis, MMP-11 was shown to confer resistance to anoikis, a process of apoptosis induction in absence of attachment to the extracellular matrix [62], a process frequently observed in cancer cells [63]. In this context, CD147 has also been described as a suppressor of anoikis by contributing to the malignant phenotype in breast cancer [64] and hepatocellular carcinoma [65].

Our group has previously shown that CD147 also induces expression of the urokinase plasminogen activator system, uPA/uPAR/PAI-1, in melanoma, breast and ovary tumor cells, further increasing its proteolytic and invasion potential in vitro and in vivo [66]. Indeed, increasing CD147 expression experimentally in human breast cancer cells greatly enhanced tumor growth and metastases in nude mice and was associated with an increase in MMPs and urokinase production in the tumors $[66,67]$. By transcriptome analysis of individual tumor cells isolated from bone marrow of cancer patients and comparative genomic hybridization technique, CD147 was shown to be the most frequently expressed protein in primary tumors and in micrometastatic cells [68], suggesting a central role in tumor progression and early metastasis.

Furthermore, the invasive proprieties of breast cancer cells are modulated by the interaction of CD147 and hyaluronan-CD44 though the activation of EGFR-RAS-ERK pathway. Our previous demonstration that CD147 expression in epithelial mammary tumor cells is increased by the EGF/EGFR system [69] suggests that the activation of EGFR signaling may account, at least partially, to the increased expression of CD147 observed in most carcinomas and to the therapeutic potential of EGFR inhibitors. More recently, the role of CD147 in promoting tumor progression and metastasis was also reported in head and neck squamous carcinoma through the NF- $\mathrm{kB}$ pathway [70].

\section{CD147 Regulates Tumors Cells Adhesion}

Integrins are major cell surface adhesive receptors composed of $\alpha$ - and $\beta$-chain heterocomplexes that mediate cell matrix adhesion and migration, playing an important role in the invasive process of tumor cells. Integrins control ECM remodeling by the regulation of the localization and activity of proteases [71]. Several studies have described CD147-integrin interactions, which can regulate adhesion and migration in cancer cells. CD147 forms complexes with $\alpha 3 \beta 1$ and $\alpha 6 \beta 1$ integrins at cell-cell contact [72], an interaction that promotes cancer invasiveness by inducing MMP synthesis via a focal adhesion kinase (FAK)-PI3K signaling pathway [73,74].

In human hepatoma cells, overexpression of CD147 was shown to promote invasion and metastasis via $\alpha 3 \beta 1$ FAK-paxillin and FAK-PI3K-Ca2+ pathways [75]. Furthermore, $\alpha 3 \beta 1$ and CD147 co-localize on human 7721 hepatoma cells [76]. In oral cancer cells, the interaction of CD147 with $\beta 6$ integrin was shown to cooperate with Fyn, a Src family kinase, in modulating MT1-MMP activity [77]. CD147 and MT1-MMP were shown to be in close proximity within invadopodia-like structures [78]. CD147 knockdown decreased the ability of prostate cancer cells to form filopodia and promote cell adhesion, which demonstrate the capacity of CD147 to regulated cytoskeleton rearrangement [79].

Our study, using a transcriptomic approach aimed at identifying CD147 regulated partners involved in cell adhesion and invasion, revealed Kindlin-3 (an integrin partner), to be inversely regulated by CD147 [80]. Kindlin-3 (also called FERMT3 or Mig2B), is an integrin-interacting focal adhesion protein that mediates integrin activation [81]. Kindlin-3 has been implicated in $\beta 2$ integrin activation in leukocytes and was shown to promote their adhesion and endothelial transmigration [82,83]. Recently we have shown that Kindlin-3 acts as a tumor suppressor in solid tumors in vitro and in vivo [84]. Functional studies allowed us to demonstrate in melanoma models, that Kindlin-3 is involved in CD147 regulation of $\beta 1$ integrin-mediated adhesion [80]. 


\section{CD147 Promotes Tumor Angiogenesis}

CD147 was also shown to be involved in tumor angiogenesis, a key component of the tumor microenvironment. MMP expression induced by CD147 in both tumor and stromal compartments in turn releases biologically active angiogenic growth factors from matrix-bound complexes. In 2005, Tang et al. showed that CD147 stimulates tumor angiogenesis by increasing VEGF and MMP expression levels in both tumor and stromal compartments [85]. Our studies have shown that tumoral CD147 increased the production by endothelial cells of VEGF soluble isoforms (particularly the most angiogenic isoforms) and of its main receptor VEGFR-2 through the transcription factor HIF-2 $\alpha$, both in vitro and in experimental tumor models in vivo. Moreover, CD147 promotes capillary-like formation, migration and cell survival through VEGFR-2 and its ligand VEGF [10]. We have also shown that this regulation of VEGF/VEGFR-2 by CD147 is not limited to endothelial cells and can be also observed in melanoma tumor cells leading to an increase of their malignant properties [86]. Further studies allowed us to identify a unique mechanism of action of CD147, showing that its direct interaction with VEGFR-2 on the plasma membrane is required for VEGF induced VEGFR-2 activation. This VEGFR-2 co-receptor role of CD147 has been studied using computational docking analyses and mutagenesis and led to the identification of a molecular binding site in the extracellular domain of CD147 located close to the cell membrane and containing the amino acids 195/199. The overexpression of CD147 in cancer is able to further potentiate VEGFR-2 activation, suggesting that a combinatory therapy of an antiangiogenic drug together with an inhibitor of CD147/VEGFR-2 interaction may have a greater impact on inhibiting angiogenesis and malignancy [87].

CD147 is also implicated in lactate efflux, via its cotransporter monocarboxylate transporter 4. Indeed, MCT4 regulates CD147 maturation and trafficking to the plasma membrane in breast cancer cells [88]. Accumulation of lactic acid in the ECM is also known to promote angiogenesis via the increase of VEGF/VEGFR-2 synthesis by tumor and endothelial cells, which reinforce the role of CD147 in the regulation of tumor angiogenesis.

\section{CD147 Therapeutic Targeting Strategies}

Drug resistance is a major issue in cancer therapy that promotes treatment failure and patients' relapse. A big challenge is the identification of those patients who will develop a therapy resistance and the setup of more effective alternative therapeutic strategies. A number of studies brought several levels of evidence that converge to a role of CD147 in drug resistance. CD147/CD98hc complex (a high glycosylated chain linked with a low glycosylated chain highly expressed on human tumor cells) is found overexpressed in cisplatin-resistant cancer cell lines [89]. CD147 expression increased chemotherapeutic drug resistance (Doxorubicin, BCNU, Taxol and Vincristine) via hyaluronan [90] and CD44 interaction, including receptor tyrosine kinase, ABS transporter and MCTs activities facilitating drug efflux with resistance to cisplatin and methotrexate in head and neck cancer [91], to cisplatin in lung cancer [92], and to vincristine in lymphoma [93]. Cooperation between CD147 and the lymphatic vessel endothelial hyaluronan receptor-1 (LYVE-1) was also described in the regulation of chemoresistance in lymphoma through upregulation of the drug transporter/ABCG2 (BCRP, the breast cancer resistance protein) [94]. Another interaction between CD147 and ABCG2 has been involved in breast cancer chemoresistance. Indeed, CD147 can bind to ABCG2 to form a complex that maintains it stability [51]. In the light of these works, CD147-targeted therapy could be a potential approach to bypass such drug resistance.

An antibody (MEM-M6/1) directed against CD147 and MCT-1 interaction was shown to induce necrosis-like cell death in colon cancer cells and melanoma cells. Moreover, MEM-M6/1 inhibited the lactate release [95]. More recently, a drug-screening assay identified Acriflavine (ACF), a small molecule responsible for the inhibition of CD147 and MCT-4 interaction and as a result of glioblastoma tumor growth and angiogenesis [96].

CD147 blockade with a specific antibody strategy inhibited secretion of MMP-9 and VEGF in a dose-dependent manner. Indeed, the antibody $(161-\mathrm{Ab})$ reduced in vivo tumor growth even when used 
in well-established tumors and decreased development of metastasis. Interestingly, the 161-Ab antibody showed a better effect at the lower doses than higher ones [97]. In pancreatic cancer, antibody 059-053 directed against CD147, combined with gemcitabine, suppressed tumor growth and decreased tumor cell survival in xenograft mouse models [98]. Another anti-CD147 monoclonal antibody (CNTO3899) induced tumor cell apoptosis with an increase of caspase 3 and caspase 8 in human head and neck tumor tissues [99]. CD147 and MMP-9 expression led to EGFR expression and contributed to tumor progression [69]. Anti-CD147 therapy led to synergy in combination with inhibition of EGFR and reduced head and neck squamous cell carcinoma (HNSCC) cell proliferation and migration [100]. In 2006, Wang et al. produced four antibodies against CD147 and observed two different effects in hepatocellular carcinoma. The antibodies 1B3 and 3B3 were able to inhibit MMP-2 secretion and cell invasion while the two others (HAb18Gedomab1 and HAb18Gedomab2) showed opposite effects. This discrepancy was explained by the fact that there are two different epitopes in the extracellular domain that appear to differently control MMPs production, one an agonist, and the other an antagonist [101]. Further studies identified the residues ${ }^{22}$ AAGTVFTTVEDLGSKILLTCSLNDSATEV ${ }^{50}$ critical for MMPs induction [102].

To target CD147, a therapeutically agent Licartin (generic name $\left(\mathrm{I}^{131}\right)$ metuximab injection) was developed as an anti-CD147 monoclonal antibody HAb18 [103] conjugated to the radioisotope $\mathrm{I}^{131}$. In phase I/II trials, the Licartin was shown to be safe and was officially approved by the China State Food and Drug Administration (SFDA, Registration No. S20050039) [104]. A randomized trial showed that Licartin can prevent relapse after liver transplantation in hepatocellular carcinoma [105]. More recently, HAb18 was shown to sensitized pancreatic cancer cells to chemoradiotherapy (gemcitabine and genfitinib) through suppressing STAT3 pathway [106]. Although Licartin has been efficient against liver cancer, its radioactive $\mathrm{I}^{131}$ component would limit its application.

Different forms of the anti-CD147 HAb18 were developed, a chimeric antibody, cHAb18, containing variable heavy and light chains of the HAb18 antibody and constant regions of human IgG1 $\gamma 1$, modulated cytoskeleton rearrangement via FAK-PI3K-AKT signaling pathway and inhibited invasion and metastasis in hepatocellular carcinoma [74]. HcHAb18 antibody conjugates with a cytotoxic drug that is a maytansinoid derivative (DM1) to promote antitumor activity in lung cancer [107].

Beside the anti-CD147 antibody strategy, a small molecule (AC-73) inhibitor of CD147 dimerization has been shown to decrease MMP-2 production via CD147-ERK-STAT3-MMP-2 pathway in hepatocellular carcinoma. AC-73 permitted the loss of invasiveness and decrease motility, resulting in the inhibition of metastasis formation [108]. The overexpression of CD147 in acute myeloid leukemia cells was shown to promote cell proliferation. AC-73 treatment led to the inhibition of leukemic cells (NB4 and NB4-R4) proliferation via the inactivation of the ERK-STAT3 pathway, as well as autophagy induction. Moreover, AC-73 was able to enhance the sensitivity to chemotherapeutic treatment and allowed a decrease in chemotherapy dosing (arabinosylcytosine and arsenic trioxide) [109].

Sato et al. reported that high expression of CD147 in renal cell carcinoma (RCC) is associated with resistance to the anti-tyrosine kinase receptor inhibitor, sunitinib, suggesting therefore that CD147 blockage in association to tyrosine kinase receptors inhibitors could restore sensitivity to such targeted therapy in RCC [110].

\section{CD147 as a Prognostic Biomarker}

Numerous studies underscored the implication of CD147 in tumor progression, suggesting its role in tumor prognosis. CD147 expression was found to be increased in more than 20 types of cancers from different organs and its overexpression has been shown to be constantly associated with poor tumor outcome (Table 1), and hence to represent a strong prognostic impact [111] including overall survival and progression free survival. 
Table 1. Studies reporting CD147 as a prognostic biomarker.

\begin{tabular}{|c|c|c|c|c|c|}
\hline Reference & First Author & Year & Type of Cancer & Sample Size & Comments \\
\hline [113] & Si et al. & 2003 & Bone cancer & 19 & $\begin{array}{l}\text { CD147 expression associated with progression and } \\
\text { aggressiveness }\end{array}$ \\
\hline [121] & Davidson et al. & 2003 & Ovarian cancer & 130 & $\begin{array}{l}\text { CD147 is expressed in all sites (effusions, primary } \\
\text { tumor and solid metastases) and predict } \\
\text { poor prognosis }\end{array}$ \\
\hline [119] & Reimers et al. & 2004 & Breast cancer & 2222 & $\begin{array}{l}\text { CD147 expression in primary tumor predicts a } \\
\text { poor prognosis }\end{array}$ \\
\hline [116] & $\begin{array}{l}\text { Vigneswaran et } \\
\text { al. }\end{array}$ & 2006 & Oral cancer & 140 & $\begin{array}{l}\text { CD147 overexpress in advanced primary and } \\
\text { metastatic tumors }\end{array}$ \\
\hline [129] & Zheng et al. & 2006 & $\begin{array}{l}\text { Gastric } \\
\text { carcinoma }\end{array}$ & 319 & CD147 expression linked to tumor size \\
\hline [127] & Als et al. & 2007 & Bladder cancer & 124 & $\begin{array}{l}\text { CD147 expression predict response to } \\
\text { Cisplatin-containing chemotherapy }\end{array}$ \\
\hline [117] & Sienel et al. & 2008 & Lung cancer & 150 & $\begin{array}{c}\text { Membrane localization of CD147 was associated } \\
\text { with poor survival independently of MMP-2 } \\
\text { and MMP-9 }\end{array}$ \\
\hline [125] & Madigan et al. & 2008 & Prostate cancer & 120 & Higher expression of CD147 in high grades \\
\hline [123] & Liang et al. & 2009 & Renal cancer & 53 & $\begin{array}{l}\text { CD147 expression correlated with VEGF expression } \\
\text { and played a role in progression }\end{array}$ \\
\hline [132] & Fu et al. & 2010 & $\begin{array}{l}\text { Acute myeloid } \\
\text { leukemia }\end{array}$ & 62 & $\begin{array}{c}\text { Co-expression of CD147 and VEGF promote } \\
\text { unfavorable prognosis }\end{array}$ \\
\hline [131] & Stenzinger et al. & 2011 & $\begin{array}{l}\text { Colorectal } \\
\text { cancer }\end{array}$ & 285 & CD147 expression decreased survival \\
\hline [115] & Lescaille et al. & 2012 & Oral cancer & 20 & CD147 expression increased with invasive stage \\
\hline [126] & Zhong et al. & 2012 & Prostate cancer & 240 & $\begin{array}{l}\text { CD147 expression can serve as a significant marker } \\
\text { for progression }\end{array}$ \\
\hline [122] & Yang et al. & 2013 & Glioblastoma & 206 & $\begin{array}{c}\text { High CD147 expression mediated poor } \\
\text { overall survival }\end{array}$ \\
\hline [124] & Rabien et al. & 2013 & Renal cancer & 395 & CD147 expression increased only with progression \\
\hline [128] & Hemdan et al. & 2015 & Bladder cancer & 250 & $\begin{array}{l}\text { Strong expression of CD147 promoted worse } \\
\text { response to neoadjuvant chemotherapy }\end{array}$ \\
\hline [112] & Caudron et al. & 2016 & Melanoma & 196 & $\begin{array}{l}\text { High CD147 expression associated with metastatic } \\
\text { potential and short survival }\end{array}$ \\
\hline [118] & Liu et al. & 2017 & Lung cancer & 72 & $\begin{array}{l}\text { High CD147 in serum-mediated metastasis and } \\
\text { advanced stage }\end{array}$ \\
\hline [130] & Li et al. & 2017 & $\begin{array}{l}\text { Esophagus } \\
\text { cancer }\end{array}$ & $\begin{array}{c}17 \text { studies } \\
\text { (1140 samples) }\end{array}$ & $\begin{array}{l}\text { Worse survival and poor prognosis with CD147 } \\
\text { strong expression }\end{array}$ \\
\hline [114] & Arora et al. & 2018 & $\begin{array}{l}\text { Oral squamous } \\
\text { cell carcinoma }\end{array}$ & 100 & CD147 intensity associated with different grades \\
\hline [120] & Liu et al. & 2018 & Breast cancer & 1174 & $\begin{array}{l}\mathrm{CD} 147 \text { expression mediated survival in } \\
\text { chemotherapy-treated patients }\end{array}$ \\
\hline
\end{tabular}

In our studies, using a large series of 196 cutaneous melanomas including primary and metastatic melanomas, we showed that high CD147 expression, assessed by immunohistochemistry, was significantly associated with the metastatic potential and with a reduced overall survival in primary melanoma patients. CD147 expression level was correlated with Clark level, ulceration status and more importantly with the Breslow index, which was associated with prognosis. In multivariate analysis, CD147 remains an independent prognostic biomarker and emerged as an important factor in the aggressive behavior of melanoma [112]. The prognostic value of CD147 expression was also shown in bone cancer. Higher expression was found in clinical stage III compared to stage I/II and was associated with aggressiveness of tumor bone cells [113]. A significant association between the expression of CD147 protein and oral squamous carcinoma (OSCC) stage was reported in a cohort of 100 tissue blocks [114]. Our previous studies in OSCC tumors demonstrated increased expression of CD147 compared to dysplastic lesions. A similar expression pattern was observed in the precancerous and invasive corresponding oral tumoral cell lines [115]. Similarly, Vigneswaren et al. reported CD147 expression in dysplastic leukoplakias, which was correlated with the degree of dysplasia. This expression was greatly increased with progression to primary and metastatic OSCC. These studies imply that overexpression of CD147 can occur at a very early stage of oral carcinogenesis and may contribute to OSCC tumorigenesis [116].

Other studies have also reported a correlation between CD147 levels and prognosis. In a cohort of 150 primary lung adenocarcinomas, Sienel et al. showed that membranous staining of CD147 was associated with shortened survival independently of MMP-2 and MMP-9 expression. This study 
suggests, therefore, that the prognostic predictor role of CD147 could be unrelated to its function as inducer of MMPs [117]. More recently in 2017, Liu et al. reported that CD147 overexpression within the tumor lesions of non-small lung cancer was associated with lymph node metastasis and progression to more advanced stages. In addition, high CD147 levels in the serums of those patients was also associated with cancer progression [118].

In a series of 2222 human breast cancer tissues, CD147 expression level assessed by immunohistochemistry was associated with tumor grade and also with tumor size. CD147 expression was detected in most micrometastatic tumor cells. More importantly, high CD147 expression level was a strong and independent predictor of shorter survival [119]. Recently in a large series of 1174 breast cancer subtypes, CD147 expression was correlated with high tumor grade, presence of necrosis and high Ki67 expression [120]. Furthermore, CD147 expression was associated with poor survival in patients with triple-negative breast cancer subtype treated with chemotherapy [120]. In ovarian cancer, CD147 was detected in primary tumors and in metastases sites and its expression in the primary tumors was correlated with poor survival [121]. Increased expression of CD147 was also reported in glioblastoma, where it was much increased compared to normal brain tissues and its overexpression was associated with poor rates of survival of patients overall [122].

In a cohort of 53 renal cancers, combination of CD147 and VEGF expression was found to predict tumor prognosis. VEGF expression correlated with CD147 expression and promoted tumor progression [123]. Additionally, CD147 overexpression seemed to appear at the later, more aggressive stages of renal cancer [124]. In a cohort of 120 primary prostate cancers, the histological grade, clinical stage, nodal involvement and progression was associate with high CD147 expression [125]. Furthermore, Zhong et al. showed the CD147 overexpression as a significant predictor for metastasis and survival in prostate cancer [126]. In advanced or metastatic bladder cancer, CD147 expression predicted the response to cisplatin-containing chemotherapy. Negative CD147 expression was associated with a better response and survival to cisplatin-containing chemotherapy treatment in a cohort of 124 bladder cancer patients [127]. Moreover, this finding was also validated in the neoadjuvant setting of bladder cancer. Patients with positive CD147 expression showed an efficacy disadvantage with neoadjuvant therapy compared to patients with a negative expression of CD147 [128].

The prognosis of gastrointestinal cancers is also linked to CD147 expression. Indeed, a high level of CD147 has been shown to correlate with the progression of gastric carcinoma and elevated CD147 expression was suggested to enhance growth, with angiogenesis allowing more ability to invade into vessels [129]. A meta-analysis of 17 studies highlighted the implication of CD147 expression in the risk of esophagus cancer. Elevated expression induced invasion, metastasis and poor survival and was suggested to be important for estimating prognosis [130]. The independent worse prognostic value of CD147 expression also reported in colorectal cancers. A study evaluating a series of 285 patients with colorectal cancers have shown that CD147 increased expression was correlated with poor survival although the increase was not correlated with the clinicopathologic parameters such as stage and metastasis in this study [131].

In acute myeloid leukemia, the analysis of bone marrow biopsies from a cohort of 62 patients revealed a significant association between expression of CD147 and VEGF. Indeed, high levels of co-expression has been suggested to induce an unfavorable prognosis by supporting leukemic cell growth [132].

Together, these studies showing the association between CD147 overexpression and disease outcome in most types of cancers strengthen the importance of the role of CD147 in tumor progression and validate its potential value as a strong prognostic biomarker.

\section{Conclusions}

Tumor management strategies include earlier cancer detection and understanding of the mechanisms that drive malignancy through mediating crucial processes such as invasion, metastasis, metabolism, angiogenesis and chemoresistance. The tumor microenvironment represents a wealthy 
source for potential prognostic markers and therapeutics targets. CD147 overexpression is a worse prognostic factor of numerous types of cancers, including solid cancers as well as hematological malignancies, which is strongly based on its functions enhancing tumor cell malignant properties. Altogether, these data underscore CD147 as a promising biomarker in cancer and also, through its successful targeting, as a potential antitumor target paving the way to new anti-CD147 therapeutic strategies.

Author Contributions: Conceptualization, A.L., S.M. (Samia Mourah); writing-original draft preparation, A.L., C.R.d.M.; writing—review and editing, S.M. (Samia Mourah), S.M. (Suzanne Menashi); supervision, S.M. (Samia Mourah); project administration, S.M. (Samia Mourah); revised manuscript, C.L., F.J. All authors critically reviewed and approved the manuscript.

Funding: This article was funded by INSERM-Université de Paris and by Assistance Publique—Hôpitaux de Paris. Alexandra Landras was supported by La Ligue Nationale contre le Cancer.

Conflicts of Interest: A.L., C.R.d.M., S.M. (Suzanne Menashi) and F.J. declare no conflict of interest. C.L. declares a consulting role for Amgen, BMS, MSD, Novartis and Roche, research funding from BMS and Roche, honoraria from Amgen, BMS, Incyte, MSD, Novartis, Pfizer, Pierre Fabre and Roche and travel accommodations from BMS. S.M. (Samia Mourah). declares a consulting role for Novartis, Biocartis and Roche and research funding from Biocartis. The funders had no role in the design of the study; in the writing of the manuscript, or in the decision to publish the results.

\section{References}

1. Grzywa, T.M.; Paskal, W.; Włodarski, P.K. Intratumor and Intertumor Heterogeneity in Melanoma. Transl. Oncol. 2017, 10, 956-975. [CrossRef]

2. Liu, J.; Dang, H.; Wang, X.W. The significance of intertumor and intratumor heterogeneity in liver cancer. Exp. Mol. Med. 2018, 50, e416. [CrossRef]

3. Salvatore, V.; Teti, G.; Focaroli, S.; Mazzotti, M.C.; Mazzotti, A.; Falconi, M. The tumor microenvironment promotes cancer progression and cell migration. Oncotarget 2016, 8, 9608-9616. [CrossRef] [PubMed]

4. Zhang, L.-N.; Xin, T.; Chen, M.; Gao, P. Chemoresistance in mesenchymal lung cancer cells is correlated to high regulatory T cell presence in the tumor microenvironment. IUBMB Life 2019, 71, 986-991. [CrossRef]

5. Mahadevan, D.; Von Hoff, D.D. Tumor-stroma interactions in pancreatic ductal adenocarcinoma. Mol. Cancer Ther. 2007, 6, 1186-1197. [CrossRef] [PubMed]

6. Turunen, S.P.; Tatti-Bugaeva, O.; Lehti, K. Membrane-type matrix metalloproteases as diverse effectors of cancer progression. Biochim. Biophys. Acta Mol. Cell Res. 2017, 1864, 1974-1988. [CrossRef]

7. Gabison, E.E.; Huet, E.; Baudouin, C.; Menashi, S. Direct epithelial-stromal interaction in corneal wound healing: Role of EMMPRIN/CD147 in MMPs induction and beyond. Prog. Retin. Eye Res. 2009, 28, 19-33. [CrossRef] [PubMed]

8. Grass, G.D.; Toole, B.P. How, with whom and when: An overview of CD147-mediated regulatory networks influencing matrix metalloproteinase activity. Biosci. Rep. 2015, 36, e00283. [CrossRef]

9. Muramatsu, T. Basigin (CD147), a multifunctional transmembrane glycoprotein with various binding partners. J. Biochem. 2016, 159, 481-490. [CrossRef]

10. Bougatef, F.; Quemener, C.; Kellouche, S.; Naimi, B.; Podgorniak, M.-P.; Millot, G.; Gabison, E.E.; Calvo, F.; Dosquet, C.; Lebbe, C.; et al. EMMPRIN promotes angiogenesis through hypoxia-inducible factor-2 -mediated regulation of soluble VEGF isoforms and their receptor VEGFR-2. Blood 2009, 114, 5547-5556. [CrossRef]

11. Basil, C.F.; Zhao, Y.; Zavaglia, K.; Jin, P.; Panelli, M.C.; Voiculescu, S.; Mandruzzato, S.; Lee, H.M.; Seliger, B.; Freedman, R.S.; et al. Common cancer biomarkers. Cancer Res. 2006, 66, 2953-2961. [CrossRef] [PubMed]

12. Fan, H.; Yi, W.; Wang, C.; Wang, J. The clinicopathological significance and prognostic value of EMMPRIN overexpression in cancers: Evidence from 39 cohort studies. Oncotarget 2017, 8, 82643-82660. [CrossRef] [PubMed]

13. Yan, L.; Zucker, S.; Toole, B.P. Roles of the multifunctional glycoprotein, emmprin (basigin; CD147), in tumour progression. Thromb. Haemost. 2005, 93, 199-204. [CrossRef] [PubMed]

14. Biswas, C.; Zhang, Y.; DeCastro, R.; Guo, H.; Nakamura, T.; Kataoka, H.; Nabeshima, K. The Human Tumor Cell-derived Collagenase Stimulatory Factor (Renamed EMMPRIN) Is a Member of the Immunoglobulin Superfamily. Cancer Res. 1995, 55, 434-439. 
15. Kaname, T.; Miyauchi, T.; Kuwano, A.; Matsuda, Y.; Muramatsu, T.; Kajii, T. Mapping basigin (BSG), a member of the immunoglobulin superfamily, to 19p13.3. Cytogenet. Cell Genet. 1993, 64, 195-197. [CrossRef]

16. Liao, C.-G.; Kong, L.-M.; Song, F.; Xing, J.-L.; Wang, L.-X.; Sun, Z.-J.; Tang, H.; Yao, H.; Zhang, Y.; Wang, L.; et al. Characterization of Basigin Isoforms and the Inhibitory Function of Basigin-3 in Human Hepatocellular Carcinoma Proliferation and Invasion. Mol. Cell. Biol. 2011, 31, 2591-2604. [CrossRef]

17. Hanna, S.M.; Kirk, P.; Holt, O.J.; Puklavec, M.J.; Brown, M.H.; Barclay, A.N. A novel form of the membrane protein CD147 that contains an extra Ig-like domain and interacts homophilically. BMC Biochem. 2003, 4, 17. [CrossRef]

18. Belton, R.J.; Chen, L.; Mesquita, F.S.; Nowak, R.A. Basigin-2 Is a Cell Surface Receptor for Soluble Basigin Ligand. J. Biol. Chem. 2008, 283, 17805-17814. [CrossRef]

19. Muramatsu, T.; Miyauchi, T. Basigin (CD147): A multifunctional transmembrane protein involved in reproduction, neural function, inflammation and tumor invasion. Histol. Histopathol. 2003, 18, 981-987.

20. Yu, X.-L.; Hu, T.; Du, J.-M.; Ding, J.-P.; Yang, X.-M.; Zhang, J.; Yang, B.; Shen, X.; Zhang, Z.; Zhong, W.-D.; et al. Crystal structure of HAb18G/CD147: Implications for immunoglobulin superfamily homophilic adhesion. J. Biol. Chem. 2008, 283, 18056-18065. [CrossRef]

21. Fadool, J.M.; Linser, P.J. Evidence for the formation of multimeric forms of the 5A11/HT7 antigen. Biochem. Biophys. Res. Commun. 1996, 229, 280-286. [CrossRef] [PubMed]

22. Yoshida, S.; Shibata, M.; Yamamoto, S.; Hagihara, M.; Asai, N.; Takahashi, M.; Mizutani, S.; Muramatsu, T.; Kadomatsu, K. Homo-oligomer formation by basigin, an immunoglobulin superfamily member, via its N-terminal immunoglobulin domain. Eur. J. Biochem. 2000, 267, 4372-4380. [CrossRef] [PubMed]

23. Schmidt, R.; Bültmann, A.; Fischel, S.; Gillitzer, A.; Cullen, P.; Walch, A.; Jost, P.; Ungerer, M.; Tolley, N.D.; Lindemann, S.; et al. Extracellular Matrix Metalloproteinase Inducer (CD147) Is a Novel Receptor on Platelets, Activates Platelets, and Augments Nuclear Factor kB-Dependent Inflammation in Monocytes. Circ. Res. 2008, 102, 302-309. [CrossRef] [PubMed]

24. Knutti, N.; Kuepper, M.; Friedrich, K. Soluble extracellular matrix metalloproteinase inducer (EMMPRIN, $\mathrm{EMN}$ ) regulates cancer-related cellular functions by homotypic interactions with surface CD147. FEBS J. 2015, 282, 4187-4200. [CrossRef]

25. Cui, H.-Y.; Guo, T.; Wang, S.-J.; Zhao, P.; Dong, Z.-S.; Zhang, Y.; Jiang, J.-L.; Chen, Z.-N.; Yu, X.-L. Dimerization is essential for HAb18G/CD147 promoting tumor invasion via MAPK pathway. Biochem. Biophys. Res. Commun. 2012, 419, 517-522. [CrossRef]

26. Aoki, M.; Koga, K.; Miyazaki, M.; Hamasaki, M.; Koshikawa, N.; Oyama, M.; Kozuka-Hata, H.; Seiki, M.; Toole, B.P.; Nabeshima, K. CD73 complexes with emmprin to regulate MMP-2 production from co-cultured sarcoma cells and fibroblasts. BMC Cancer 2019, 19, 1-13. [CrossRef]

27. Xu, J.; Lu, Y.; Qiu, S.; Chen, Z.-N.; Fan, Z. A novel role of EMMPRIN/CD147 in transformation of quiescent fibroblasts to cancer-associated fibroblasts by breast cancer cells. Cancer Lett. 2013, 335, 380-386. [CrossRef]

28. Tang, W.; Chang, S.B.; Hemler, M.E. Links between CD147 Function, Glycosylation, and Caveolin-1. Mol. Biol. Cell 2004, 15, 4043-4050. [CrossRef]

29. Egawa, N.; Koshikawa, N.; Tomari, T.; Nabeshima, K.; Isobe, T.; Seiki, M. Membrane Type 1 Matrix Metalloproteinase (MT1-MMP/MMP-14) Cleaves and Releases a 22-kDa Extracellular Matrix Metalloproteinase Inducer (EMMPRIN) Fragment from Tumor Cells. J. Biol. Chem. 2006, 281, 37576-37585. [CrossRef]

30. Sidhu, S.S.; Mengistab, A.T.; Tauscher, A.N.; LaVail, J.; Basbaum, C. The microvesicle as a vehicle for EMMPRIN in tumor-stromal interactions. Oncogene 2004, 23, 956. [CrossRef]

31. Albrechtsen, R.; Albrechtsen, N.J.W.; Gnosa, S.; Schwarz, J.; Dyrskjøt, L.; Kveiborg, M. Identification of ADAM12 as a Novel Basigin Sheddase. Int. J. Mol. Sci. 2019, 20, 1957. [CrossRef] [PubMed]

32. Kuang, Y.H.; Liu, Y.J.; Tang, L.L.; Wang, S.M.; Yan, G.J.; Liao, L.Q. Plasma soluble cluster of differentiation 147 levels are increased in breast cancer patients and associated with lymph node metastasis and chemoresistance. Hong Kong Med. J. 2018, 24, 252-260. [CrossRef] [PubMed]

33. Lee, A.; Rode, A.; Nicoll, A.; Maczurek, A.E.; Lim, L.; Lim, S.; Angus, P.; Kronborg, I.; Arachchi, N.; Gorelik, A.; et al. Circulating CD147 predicts mortality in advanced hepatocellular carcinoma. J. Gastroenterol. Hepatol. 2016, 31, 459-466. [CrossRef] [PubMed] 
34. Kirk, P.; Wilson, M.C.; Heddle, C.; Brown, M.H.; Barclay, A.N.; Halestrap, A.P. CD147 is tightly associated with lactate transporters MCT1 and MCT4 and facilitates their cell surface expression. EMBO J. 2000, 19, 3896-3904. [CrossRef] [PubMed]

35. Tang, W.; Hemler, M.E. Caveolin-1 regulates matrix metalloproteinases-1 induction and CD147/EMMPRIN cell surface clustering. J. Biol. Chem. 2004, 279, 11112-11118. [CrossRef] [PubMed]

36. Cho, J.Y.; Fox, D.A.; Horejsi, V.; Sagawa, K.; Skubitz, K.M.; Katz, D.R.; Chain, B. The functional interactions between CD98, $\beta 1$-integrins, and CD147 in the induction of U937 homotypic aggregation. Blood 2001, 98, 374-382. [CrossRef]

37. Li, Y.; Wu, J.; Song, F.; Tang, J.; Wang, S.-J.; Yu, X.-L.; Chen, Z.-N.; Jiang, J.-L. Extracellular Membrane-proximal Domain of HAb18G/CD147 Binds to Metal Ion-dependent Adhesion Site (MIDAS) Motif of Integrin $\beta 1$ to Modulate Malignant Properties of Hepatoma Cells. J. Biol. Chem. 2012, 287, 4759-4772. [CrossRef]

38. Le Floch, R.; Chiche, J.; Marchiq, I.; Naiken, T.; Ilc, K.; Murray, C.M.; Critchlow, S.E.; Roux, D.; Simon, M.-P.; Pouysségur, J. CD147 subunit of lactate/H+ symporters MCT1 and hypoxia-inducible MCT4 is critical for energetics and growth of glycolytic tumors. Proc. Natl. Acad. Sci. USA 2011, 108, 16663-16668. [CrossRef]

39. Hanahan, D.; Weinberg, R.A. Hallmarks of Cancer: The Next Generation. Cell 2011, 144, 646-674. [CrossRef]

40. Marchiq, I.; Albrengues, J.; Granja, S.; Gaggioli, C.; Pouysségur, J.; Simon, M.-P. Knock out of the BASIGIN/CD147 chaperone of lactate/H+ symporters disproves its pro-tumour action via extracellular matrix metalloproteases (MMPs) induction. Oncotarget 2015, 6, 24636-24648. [CrossRef]

41. Granja, S.; Marchiq, I.; Floch, R.L.; Moura, C.S.; Baltazar, F.; Pouysségur, J. Disruption of BASIGIN decreases lactic acid export and sensitizes non-small cell lung cancer to biguanides independently of the LKB1 status. Oncotarget 2014, 6, 6708-6721. [CrossRef] [PubMed]

42. Huang, P.; Chang, S.; Jiang, X.; Su, J.; Dong, C.; Liu, X.; Yuan, Z.; Zhang, Z.; Liao, H. RNA interference targeting CD147 inhibits the proliferation, invasiveness, and metastatic activity of thyroid carcinoma cells by down-regulating glycolysis. Int. J. Clin. Exp. Pathol. 2015, 8, 309-318. [PubMed]

43. Walters, D.K.; Arendt, B.K.; Jelinek, D.F. CD147 regulates the expression of MCT1 and lactate export in multiple myeloma cells. Cell Cycle 2013, 12, 3175-3183. [CrossRef] [PubMed]

44. Jia, L.; Wang, S.; Zhou, H.; Cao, J.; Hu, Y.; Zhang, J. Caveolin-1 up-regulates CD147 glycosylation and the invasive capability of murine hepatocarcinoma cell lines. Int. J. Biochem. Cell Biol. 2006, 38, 1584-1593. [CrossRef]

45. Xu, D.; Hemler, M.E. Metabolic activation-related CD147-CD98 complex. Mol. Cell. Proteom. 2005, 4, 1061-1071. [CrossRef]

46. Wang, S.; Cui, H.; Liu, Y.; Zhao, P.; Zhang, Y.; Fu, Z.; Chen, Z.-N.; Jiang, J. CD147 promotes Src-dependent activation of Rac1 signaling through STAT3/DOCK8 during the motility of hepatocellular carcinoma cells. Oncotarget 2015, 6, 243. [CrossRef]

47. Tang, Y.; Nakada, M.T.; Rafferty, P.; Laraio, J.; McCabe, F.L.; Millar, H.; Cunningham, M.; Snyder, L.A.; Bugelski, P.; Yan, L. Regulation of vascular endothelial growth factor expression by EMMPRIN via the PI3K-Akt signaling pathway. Mol. Cancer Res. 2006, 4, 371-377. [CrossRef]

48. Doyle, L.A.; Yang, W.; Abruzzo, L.V.; Krogmann, T.; Gao, Y.; Rishi, A.K.; Ross, D.D. A multidrug resistance transporter from human MCF-7 breast cancer cells. Proc. Natl. Acad. Sci. USA 1998, 95, 15665-15670. [CrossRef]

49. Allikmets, R.; Schriml, L.M.; Hutchinson, A.; Romano-Spica, V.; Dean, M. A Human Placenta-specific ATP-Binding Cassette Gene (ABCP) on Chromosome 4q22 That Is Involved in Multidrug Resistance. Cancer Res. 1998, 58, 5337-5339.

50. Woodward, O.M.; Köttgen, A.; Coresh, J.; Boerwinkle, E.; Guggino, W.B.; Köttgen, M. Identification of a urate transporter, ABCG2, with a common functional polymorphism causing gout. Proc. Natl. Acad. Sci. USA 2009, 106, 10338-10342. [CrossRef]

51. Zhou, S.; Liao, L.; Chen, C.; Zeng, W.; Liu, S.; Su, J.; Zhao, S.; Chen, M.; Kuang, Y.; Chen, X.; et al. CD147 mediates chemoresistance in breast cancer via ABCG2 by affecting its cellular localization and dimerization. Cancer Lett. 2013, 337, 285-292. [CrossRef] [PubMed]

52. Zhao, S.; Chen, C.; Liu, S.; Zeng, W.; Su, J.; Wu, L.; Luo, Z.; Zhou, S.; Li, Q.; Zhang, J.; et al. CD147 promotes MTX resistance by immune cells through up-regulating ABCG2 expression and function. J. Dermatol. Sci. 2013, 70, 182-189. [CrossRef] 
53. Yang, H.; Chen, J.; Yang, J.; Qiao, S.; Zhao, S.; Yu, L. Cyclophilin A is upregulated in small cell lung cancer and activates ERK1/2 signal. Biochem. Biophys. Res. Commun. 2007, 361, 763-767. [CrossRef] [PubMed]

54. Huang, C.; Sun, Z.; Sun, Y.; Chen, X.; Zhu, X.; Fan, C.; Liu, B.; Zhao, Y.; Zhang, W. Association of increased ligand cyclophilin A and receptor CD147 with hypoxia, angiogenesis, metastasis and prognosis of tongue squamous cell carcinoma. Histopathology 2012, 60, 793-803. [CrossRef] [PubMed]

55. Yurchenko, V.; Pushkarsky, T.; Li, J.-H.; Dai, W.W.; Sherry, B.; Bukrinsky, M. Regulation of CD147 cell surface expression: Involvement of the proline residue in the CD147 transmembrane domain. J. Biol. Chem. 2005, 280, 17013-17019. [CrossRef] [PubMed]

56. Guo, H.; Zucker, S.; Gordon, M.K.; Toole, B.P.; Biswas, C. Stimulation of Matrix Metalloproteinase Production by Recombinant Extracellular Matrix Metalloproteinase Inducer from Transfected Chinese Hamster Ovary Cells. J. Biol. Chem. 1997, 272, 24-27. [CrossRef]

57. Guo, H.; Li, R.; Zucker, S.; Toole, B.P. EMMPRIN (CD147), an inducer of matrix metalloproteinase synthesis, also binds interstitial collagenase to the tumor cell surface. Cancer Res. 2000, 60, 888-891.

58. Kanekura, T.; Chen, X.; Kanzaki, T. Basigin (cd147) is expressed on melanoma cells and induces tumor cell invasion by stimulating production of matrix metalloproteinases by fibroblasts. Int. J. Cancer 2002, 99, 520-528. [CrossRef]

59. Rucci, N.; Millimaggi, D.; Mari, M.; Del Fattore, A.; Bologna, M.; Teti, A.; Angelucci, A.; Dolo, V. Receptor Activator of NF- B Ligand Enhances Breast Cancer-Induced Osteolytic Lesions through Upregulation of Extracellular Matrix Metalloproteinase Inducer/CD147. Cancer Res. 2010, 70, 6150-6160. [CrossRef]

60. Caudroy, S.; Polette, M.; Nawrocki-Raby, B.; Cao, J.; Toole, B.P.; Zucker, S.; Birembaut, P. EMMPRIN-mediated MMP regulation in tumor and endothelial cells. Clin. Exp. Metastasis 2002, 19, 697-702. [CrossRef]

61. Liu, Y.; Xin, T.; Jiang, Q.; Huang, D.; Shen, W.; Li, L.; Lv, Y.; Jin, Y.; Song, X.; Teng, C. CD147, MMP9 expression and clinical significance of basal-like breast cancer. Med. Oncol. 2013, 30, 366. [CrossRef] [PubMed]

62. Tian, X.; Ye, C.; Yang, Y.; Guan, X.; Dong, B.; Zhao, M.; Hao, C. Expression of CD147 and matrix metalloproteinase-11 in colorectal cancer and their relationship to clinicopathological features. J. Transl. Med. 2015, 13, 337. [CrossRef] [PubMed]

63. Paoli, P.; Giannoni, E.; Chiarugi, P. Anoikis molecular pathways and its role in cancer progression. Biochim. Biophys. Acta BBA Mol. Cell Res. 2013, 1833, 3481-3498. [CrossRef] [PubMed]

64. Yang, J.-M.; O’Neill, P.; Jin, W.; Foty, R.; Medina, D.J.; Xu, Z.; Lomas, M.; Arndt, G.M.; Tang, Y.; Nakada, M.; et al. Extracellular Matrix Metalloproteinase Inducer (CD147) Confers Resistance of Breast Cancer Cells to Anoikis through Inhibition of Bim. J. Biol. Chem. 2006, 281, 9719-9727. [CrossRef]

65. Ke, X.; LI, L.; Dong, H.-L.; Chen, Z.-N. Acquisition of anoikis resistance through CD147 upregulation: A new mechanism underlying metastasis of hepatocellular carcinoma cells. Oncol. Lett. 2012, 3, 1249-1254. [CrossRef]

66. Quemener, C.; Gabison, E.E.; Naïmi, B.; Lescaille, G.; Bougatef, F.; Podgorniak, M.P.; Labarchède, G.; Lebbé, C.; Calvo, F.; Menashi, S.; et al. Extracellular matrix metalloproteinase inducer up-regulates the urokinase-type plasminogen activator system promoting tumor cell invasion. Cancer Res. 2007, 67, 9-15. [CrossRef]

67. Zucker, S.; Hymowitz, M.; Rollo, E.E.; Mann, R.; Conner, C.E.; Cao, J.; Foda, H.D.; Tompkins, D.C.; Toole, B.P. Tumorigenic potential of extracellular matrix metalloproteinase inducer. Am. J. Pathol. 2001, 158, 1921-1928. [CrossRef]

68. Klein, C.A.; Seidl, S.; Petat-Dutter, K.; Offner, S.; Geigl, J.B.; Schmidt-Kittler, O.; Wendler, N.; Passlick, B.; Huber, R.M.; Schlimok, G.; et al. Combined transcriptome and genome analysis of single micrometastatic cells. Nat. Biotechnol. 2002, 20, 387. [CrossRef]

69. Menashi, S.; Serova, M.; Ma, L.; Vignot, S.; Mourah, S.; Calvo, F. Regulation of extracellular matrix metalloproteinase inducer and matrix metalloproteinase expression by amphiregulin in transformed human breast epithelial cells. Cancer Res. 2003, 63, 7575-7580.

70. Yu, B.; Zhang, Y.; Wu, K.; Wang, L.; Jiang, Y.; Chen, W.; Yan, M. CD147 promotes progression of head and neck squamous cell carcinoma via NF-kappa B signaling. J. Cell Mol. Med. 2019, 23, 954-966. [CrossRef]

71. Desgrosellier, J.S.; Cheresh, D.A. Integrins in cancer: Biological implications and therapeutic opportunities. Nat. Rev. Cancer 2010, 10, 9-22. [CrossRef] [PubMed]

72. Berditchevski, F.; Chang, S.; Bodorova, J.; Hemler, M.E. Generation of monoclonal antibodies to integrin-associated proteins. Evidence that alpha3beta1 complexes with EMMPRIN/basigin/OX47/M6. J. Biol. Chem. 1997, 272, 29174-29180. [CrossRef] [PubMed] 
73. Li, L.; Dong, X.; Peng, F.; Shen, L. Integrin $\beta 1$ regulates the invasion and radioresistance of laryngeal cancer cells by targeting CD147. Cancer Cell Int. 2018, 18. [CrossRef] [PubMed]

74. Wang, Y.; Yuan, L.; Yang, X.-M.; Wei, D.; Wang, B.; Sun, X.-X.; Feng, F.; Nan, G.; Wang, Y.; Chen, Z.-N.; et al. A chimeric antibody targeting CD147 inhibits hepatocellular carcinoma cell motility via FAK-PI3K-Akt-Girdin signaling pathway. Clin. Exp. Metastasis 2015, 32, 39-53. [CrossRef]

75. Tang, J.; Wu, Y.-M.; Zhao, P.; Yang, X.-M.; Jiang, J.-L.; Chen, Z.-N. Overexpression of HAb18G/CD147 promotes invasion and metastasis via $\alpha 3 \beta 1$ integrin mediated FAK-paxillin and FAK-PI3K-Ca2+ pathways. Cell. Mol. Life Sci. 2008, 65, 2933-2942. [CrossRef]

76. Dai, J.; Dou, K.; Wang, C.; Zhao, P.; Lau, W.B.; Tao, L.; Wu, Y.; Tang, J.; Jiang, J.; Chen, Z. The interaction of HAb18G/CD147 with integrin $\alpha 6 \beta 1$ and its implications for the invasion potential of human hepatoma cells. BMC Cancer 2009, 9, 337. [CrossRef]

77. Ramos, D.M.; Dang, D. EMMPRIN Expression in Oral SCC Is Regulated by FYN Kinase. Anticancer. Res. 2011, 31, 1205-1209.

78. Grass, G.D.; Bratoeva, M.; Toole, B.P. Regulation of invadopodia formation and activity by CD147. J. Cell Sci. 2012, 125, 777-788. [CrossRef]

79. Zhu, H.; Zhao, J.; Zhu, B.; Collazo, J.; Gal, J.; Shi, P.; Liu, L.; Ström, A.-L.; Lu, X.; McCann, R.O.; et al. EMMPRIN Regulates Cytoskeleton Reorganization and Cell Adhesion in Prostate Cancer. Prostate 2012, 72, 72-81. [CrossRef]

80. Delyon, J.; Khayati, F.; Djaafri, I.; Podgorniak, M.-P.; Sadoux, A.; Setterblad, N.; Boutalbi, Z.; Maouche, K.; Maskos, U.; Menashi, S.; et al. EMMPRIN regulates $\beta 1$ integrin-mediated adhesion through Kindlin-3 in human melanoma cells. Exp. Dermatol. 2015, 24, 443-448. [CrossRef]

81. Moser, M.; Legate, K.R.; Zent, R.; Fässler, R. The Tail of Integrins, Talin, and Kindlins. Science 2009, 324, 895-899. [CrossRef] [PubMed]

82. Moser, M.; Bauer, M.; Schmid, S.; Ruppert, R.; Schmidt, S.; Sixt, M.; Wang, H.-V.; Sperandio, M.; Fässler, R. Kindlin-3 is required for beta2 integrin-mediated leukocyte adhesion to endothelial cells. Nat. Med. 2009, 15, 300-305. [CrossRef] [PubMed]

83. Fagerholm, S.C.; Guenther, C.; Llort Asens, M.; Savinko, T.; Uotila, L.M. Beta2-Integrins and Interacting Proteins in Leukocyte Trafficking, Immune Suppression, and Immunodeficiency Disease. Front. Immunol. 2019, 10, 254. [CrossRef] [PubMed]

84. Djaafri, I.; Khayati, F.; Menashi, S.; Tost, J.; Podgorniak, M.-P.; Sadoux, A.; Daunay, A.; Teixeira, L.; Soulier, J.; Idbaih, A.; et al. A novel tumor suppressor function of Kindlin-3 in solid cancer. Oncotarget 2014, 5, 8970-8985. [CrossRef]

85. Tang, Y.; Nakada, M.T.; Kesavan, P.; McCabe, F.; Millar, H.; Rafferty, P.; Bugelski, P.; Yan, L. Extracellular matrix metalloproteinase inducer stimulates tumor angiogenesis by elevating vascular endothelial cell growth factor and matrix metalloproteinases. Cancer Res. 2005, 65, 3193-3199. [CrossRef]

86. Bougatef, F.; Menashi, S.; Khayati, F.; Naïmi, B.; Porcher, R.; Podgorniak, M.-P.; Millot, G.; Janin, A.; Calvo, F.; Lebbé, C.; et al. EMMPRIN Promotes Melanoma Cells Malignant Properties through a HIF-2alpha Mediated Up-Regulation of VEGF-Receptor-2. PLoS ONE 2010, 5, e12265. [CrossRef]

87. Khayati, F.; Pérez-Cano, L.; Maouche, K.; Sadoux, A.; Boutalbi, Z.; Podgorniak, M.-P.; Maskos, U.; Setterblad, N.; Janin, A.; Calvo, F.; et al. EMMPRIN/CD147 is a novel coreceptor of VEGFR-2 mediating its activation by VEGF. Oncotarget 2015, 6, 9766-9780. [CrossRef]

88. Gallagher, S.M.; Castorino, J.J.; Wang, D.; Philp, N.J. Monocarboxylate transporter 4 regulates maturation and trafficking of CD147 to the plasma membrane in the metastatic breast cancer cell line MDA-MB-231. Cancer Res. 2007, 67, 4182-4189. [CrossRef]

89. Yang, H.; Zou, W.; Li, Y.; Chen, B.; Xin, X. Bridge linkage role played by CD98hc of anti-tumor drug resistance and cancer metastasis on cisplatin-resistant ovarian cancer cells. Cancer Biol. Ther. 2007, 6, 942-947.

90. Misra, S.; Ghatak, S.; Zoltan-Jones, A.; Toole, B.P. Regulation of Multidrug Resistance in Cancer Cells by Hyaluronan. J. Biol. Chem. 2003, 278, 25285-25288. [CrossRef]

91. Wang, S.J.; Bourguignon, L.Y.W. Hyaluronan and the Interaction Between CD44 and Epidermal Growth Factor Receptor in Oncogenic Signaling and Chemotherapy Resistance in Head and Neck Cancer. Arch. Otolaryngol. Head Neck Surg. 2006, 132, 771-778. [CrossRef] [PubMed] 
92. Ohashi, R.; Takahashi, F.; Cui, R.; Yoshioka, M.; Gu, T.; Sasaki, S.; Tominaga, S.; Nishio, K.; Tanabe, K.K.; Takahashi, K. Interaction between CD44 and hyaluronate induces chemoresistance in non-small cell lung cancer cell. Cancer Lett. 2007, 252, 225-234. [CrossRef] [PubMed]

93. Russo, R.I.C.; García, M.G.; Alaniz, L.; Blanco, G.; Alvarez, E.; Hajos, S.E. Hyaluronan oligosaccharides sensitize lymphoma resistant cell lines to vincristine by modulating P-glycoprotein activity and PI3K/Akt pathway. Int. J. Cancer 2008, 122, 1012-1018. [CrossRef] [PubMed]

94. Qin, Z.; Dai, L.; Bratoeva, M.; Slomiany, M.G.; Toole, B.P.; Parsons, C. Cooperative roles for emmprin and LYVE-1 in the regulation of chemoresistance for primary effusion lymphoma. Leukemia 2011, 25, 1598-1609. [CrossRef]

95. Baba, M.; Inoue, M.; Itoh, K.; Nishizawa, Y. Blocking CD147 induces cell death in cancer cells through impairment of glycolytic energy metabolism. Biochem. Biophys. Res. Commun. 2008, 374, 111-116. [CrossRef]

96. Voss, D.M.; Spina, R.; Carter, D.L.; Lim, K.S.; Jeffery, C.J.; Bar, E.E. Disruption of the monocarboxylate transporter-4-basigin interaction inhibits the hypoxic response, proliferation, and tumor progression. Sci. Rep. 2017, 7, 4292. [CrossRef]

97. Walter, M.; Simanovich, E.; Brod, V.; Lahat, N.; Bitterman, H.; Rahat, M.A. An epitope-specific novel anti-EMMPRIN polyclonal antibody inhibits tumor progression. Oncoimmunology 2015, 5, e1078056. [CrossRef]

98. Sugyo, A.; Tsuji, A.B.; Sudo, H.; Koizumi, M.; Ukai, Y.; Kurosawa, G.; Kurosawa, Y.; Saga, T.; Higashi, T. Efficacy Evaluation of Combination Treatment Using Gemcitabine and Radioimmunotherapy with 90Y-Labeled Fully Human Anti-CD147 Monoclonal Antibody 059-053 in a BxPC-3 Xenograft Mouse Model of Refractory Pancreatic Cancer. Int. J. Mol. Sci. 2018, 19, 2979. [CrossRef]

99. Dean, N.R.; Knowles, J.A.; Helman, E.E.; Aldridge, J.C.; Carroll, W.R.; Magnuson, J.S.; Clemons, L.; Ziober, B.; Rosenthal, E.L. Anti-EMMPRIN antibody treatment of head and neck squamous cell carcinoma in an ex-vivo model. Anticancer. Drugs 2010, 21, 861-867. [CrossRef]

100. Suzuki, S.; Ishikawa, K. Combined inhibition of EMMPRIN and epidermal growth factor receptor prevents the growth and migration of head and neck squamous cell carcinoma cells. Int. J. Oncol. 2014, 44, 912-917. [CrossRef]

101. Wang, L.; Ku, X.-M.; Li, Y.; Bian, H.-J.; Zhang, S.-H.; Ye, H.; Yao, X.-Y.; Li, B.-H.; Yang, X.-M.; Liao, C.-G.; et al. Regulation of matrix metalloproteinase production and tumor cell invasion by four monoclonal antibodies against different epitopes of HAb18G/CD147 extracellular domain. Hybridoma (Larchmt) 2006, 25, 60-67. [CrossRef] [PubMed]

102. Ku, X.-M.; Liao, C.-G.; Li, Y.; Yang, X.-M.; Yang, B.; Yao, X.-Y.; Wang, L.; Kong, L.-M.; Zhao, P.; Chen, Z.-N. Epitope Mapping of Series of Monoclonal Antibodies Against the Hepatocellular Carcinoma-associated Antigen HAb18G/CD147. Scand. J. Immunol. 2007, 65, 435-443. [CrossRef] [PubMed]

103. Chen, Z.; Xing, J.; Zhang, S. Anti-Human Hepatoma Monoclonal Antibody Hab18 Light/Heavy Chain Variable Region Gene, and Use Thereof. EP Patent 20030711796, 29 December 2004.

104. Chen, Z.-N.; Mi, L.; Xu, J.; Song, F.; Zhang, Q.; Zhang, Z.; Xing, J.-L.; Bian, H.-J.; Jiang, J.-L.; Wang, X.-H.; et al. Targeting radioimmunotherapy of hepatocellular carcinoma with iodine (131I) metuximab injection: Clinical Phase I/II trials. Int. J. Radiat. Oncol. Biol. Phys. 2006, 65, 435-444. [CrossRef] [PubMed]

105. Xu, J.; Shen, Z.-Y.; Chen, X.-G.; Zhang, Q.; Bian, H.-J.; Zhu, P.; Xu, H.-Y.; Song, F.; Yang, X.-M.; Mi, L.; et al. A randomized controlled trial of Licartin for preventing hepatoma recurrence after liver transplantation. Hepatology 2007, 45, 269-276. [CrossRef]

106. Fan, X.-Y.; He, D.; Sheng, C.-B.; Wang, B.; Wang, L.-J.; Wu, X.-Q.; Xu, L.; Jiang, J.-L.; Li, L.; Chen, Z.-N. Therapeutic anti-CD147 antibody sensitizes cells to chemoradiotherapy via targeting pancreatic cancer stem cells. Am. J. Transl. Res. 2019, 11, 3543-3554.

107. Huhe, M.; Lou, J.; Zhu, Y.; Zhao, Y.; Shi, Y.; Wang, B.; Sun, X.; Zhang, X.; Zhang, Y.; Chen, Z.-N. A novel antibody-drug conjugate, HcHAb18-DM1, has potent anti-tumor activity against human non-small cell lung cancer. Biochem. Biophys. Res. Commun. 2019, 513, 1083-1091. [CrossRef]

108. Fu, Z.; Wang, L.; Cui, H.; Peng, J.; Wang, S.; Geng, J.; Liu, J.; Feng, F.; Song, F.; Li, L.; et al. A novel small-molecule compound targeting CD147 inhibits the motility and invasion of hepatocellular carcinoma cells. Oncotarget 2016, 7, 9429-9447. [CrossRef] 
109. Spinello, I.; Saulle, E.; Quaranta, M.T.; Pasquini, L.; Pelosi, E.; Castelli, G.; Ottone, T.; Voso, M.T.; Testa, U.; Labbaye, C. The small-molecule compound AC-73 targeting CD147 inhibits leukemic cell proliferation, induces autophagy and increases the chemotherapeutic sensitivity of acute myeloid leukemia cells. Haematologica 2019, 104, 973-985. [CrossRef]

110. Sato, M.; Nakai, Y.; Nakata, W.; Yoshida, T.; Hatano, K.; Kawashima, A.; Fujita, K.; Uemura, M.; Takayama, H.; Nonomura, N. EMMPRIN promotes angiogenesis, proliferation, invasion and resistance to sunitinib in renal cell carcinoma, and its level predicts patient outcome. PLoS ONE 2013, 8, e74313. [CrossRef]

111. Li, Y.; Xu, J.; Chen, L.; Zhong, W.-D.; Zhang, Z.; Mi, L.; Zhang, Y.; Liao, C.-G.; Bian, H.-J.; Jiang, J.-L.; et al. HAb18G (CD147), a cancer-associated biomarker and its role in cancer detection. Histopathology 2009, 54, 677-687. [CrossRef]

112. Caudron, A.; Battistella, M.; Feugeas, J.-P.; Pages, C.; Basset-Seguin, N.; Dorval, S.M.; Brentano, E.F.; Sadoux, A.; Podgorniak, M.-P.; Menashi, S.; et al. EMMPRIN/CD147 is an independent prognostic biomarker in cutaneous melanoma. Exp. Dermatol. 2016, 25, 618-622. [CrossRef] [PubMed]

113. Si, A.I.C.; Huang, L.; Xu, J.; Kumta, S.-M.; Wood, D.; Zheng, M.H. Expression and localization of extracellular matrix metalloproteinase inducer in giant cell tumor of bone. J. Cell. Biochem. 2003, 89, 1154-1163. [CrossRef] [PubMed]

114. Arora, M.; Mane, D.R. Immunohistochemical expression of extracellular matrix metalloproteinase inducer (EMMPRIN) in normal oral mucosa, oral epithelial dysplasia and oral squamous cell carcinoma. J. Oral Maxillofac. Pathol. 2018, 22, 279-280. [PubMed]

115. Lescaille, G.; Menashi, S.; Cavelier-Balloy, B.; Khayati, F.; Quemener, C.; Podgorniak, M.P.; Naïmi, B.; Calvo, F.; Lebbe, C.; Mourah, S. EMMPRIN/CD147 up-regulates urokinase-type plasminogen activator: Implications in oral tumor progression. BMC Cancer 2012, 12, 115. [CrossRef]

116. Vigneswaran, N.; Beckers, S.; Waigel, S.; Mensah, J.; Wu, J.; Mo, J.; Fleisher, K.E.; Bouquot, J.; Sacks, P.G.; Zacharias, W. Increased EMMPRIN (CD 147) expression during oral carcinogenesis. Exp. Mol. Pathol. 2006, 80, 147-159. [CrossRef]

117. Sienel, W.; Polzer, B.; Elshawi, K.; Lindner, M.; Morresi-Hauf, A.; Vay, C.; Eder, F.; Passlick, B.; Klein, C.A. Cellular localization of EMMPRIN predicts prognosis of patients with operable lung adenocarcinoma independent from MMP-2 and MMP-9. Mod. Pathol. 2008, 21, 1130-1138. [CrossRef]

118. Liu, B.; Wan, Z.; Sheng, B.; Lin, Y.; Fu, T.; Zeng, Q.; Qi, C. Overexpression of EMMPRIN is associated with lymph node metastasis and advanced stage of non-small cell lung cancer: A retrospective study. BMC Pulm. Med. 2017, 17, 214. [CrossRef]

119. Reimers, N.; Zafrakas, K.; Assmann, V.; Egen, C.; Riethdorf, L.; Riethdorf, S.; Berger, J.; Ebel, S.; Jänicke, F.; Sauter, G.; et al. Expression of extracellular matrix metalloproteases inducer on micrometastatic and primary mammary carcinoma cells. Clin. Cancer Res. 2004, 10, 3422-3428. [CrossRef]

120. Liu, M.; Tsang, J.Y.S.; Lee, M.; Ni, Y.-B.; Chan, S.-K.; Cheung, S.-Y.; Hu, J.; Hu, H.; Tse, G.M.K. CD147 expression is associated with poor overall survival in chemotherapy treated triple-negative breast cancer. J. Clin. Pathol. 2018, 71, 1007-1014. [CrossRef]

121. Davidson, B.; Goldberg, I.; Berner, A.; Kristensen, G.B.; Reich, R. EMMPRIN (extracellular matrix metalloproteinase inducer) is a novel marker of poor outcome in serous ovarian carcinoma. Clin. Exp. Metastasis 2003, 20, 161-169. [CrossRef]

122. Yang, M.; Yuan, Y.; Zhang, H.; Yan, M.; Wang, S.; Feng, F.; Ji, P.; Li, Y.; Li, B.; Gao, G.; et al. Prognostic significance of CD147 in patients with glioblastoma. J. Neuro Oncol. 2013, 115, 19-26. [CrossRef] [PubMed]

123. Liang, Y.-X.; He, H.-C.; Han, Z.; Bi, X.-C.; Dai, Q.-S.; Ye, Y.-K.; Qin, W.-J.; Zeng, G.-H.; Zhu, G.; Xu, C.-L.; et al. CD147 and VEGF Expression in Advanced Renal Cell Carcinoma and Their Prognostic Value. Cancer Investig. 2009, 27, 788-793. [CrossRef] [PubMed]

124. Rabien, A.; Stephan, C.; Kilic, E.; Weichert, W.; Kristiansen, G.; Miller, K.; Jung, K.; Erbersdobler, A. Renal cell neoplasias: Reversion-inducing cysteine-rich protein with Kazal motifs discriminates tumor subtypes, while extracellular matrix metalloproteinase inducer indicates prognosis. J. Transl. Med. 2013, 11, 258. [CrossRef] [PubMed]

125. Madigan, M.C.; Kingsley, E.A.; Cozzi, P.J.; Delprado, W.J.; Russell, P.J.; Li, Y. The role of extracellular matrix metalloproteinase inducer protein in prostate cancer progression. Cancer Immunol. Immunother. 2008, 57, 1367-1379. [CrossRef] [PubMed] 
126. Zhong, W.; Liang, Y.; Lin, S.X.; Li, L.; He, H.; Bi, X.; Han, Z.; Dai, Q.; Ye, Y.; Chen, Q.; et al. Expression of CD147 is associated with prostate cancer progression. Int. J. Cancer 2012, 130, 300-308. [CrossRef] [PubMed]

127. Als, A.B.; Dyrskjøt, L.; von der Maase, H.; Koed, K.; Mansilla, F.; Toldbod, H.E.; Jensen, J.L.; Ulhøi, B.P.; Sengeløv, L.; Jensen, K.M.E.; et al. Emmprin and survivin predict response and survival following cisplatin-containing chemotherapy in patients with advanced bladder cancer. Clin. Cancer Res. 2007, 13, 4407-4414. [CrossRef]

128. Hemdan, T.; Malmström, P.-U.; Jahnson, S.; Segersten, U. Emmprin Expression Predicts Response and Survival following Cisplatin Containing Chemotherapy for Bladder Cancer: A Validation Study. J. Urol. 2015, 194, 1575-1581. [CrossRef]

129. Zheng, H.-C.; Takahashi, H.; Murai, Y.; Cui, Z.-G.; Nomoto, K.; Miwa, S.; Tsuneyama, K.; Takano, Y. Upregulated EMMPRIN/CD147 might contribute to growth and angiogenesis of gastric carcinoma: A good marker for local invasion and prognosis. Br. J. Cancer 2006, 95, 1371-1378. [CrossRef]

130. Li, H.; Jiang, C.; Wu, D.; Shi, S.; Liao, M.; Wang, J.; Li, Y.; Xu, Z. The prognostic and clinicopathologic characteristics of CD147 and esophagus cancer: A meta-analysis. PLoS ONE 2017, 12, e0180271. [CrossRef]

131. Stenzinger, A.; Wittschieber, D.; von Winterfeld, M.; Goeppert, B.; Kamphues, C.; Weichert, W.; Dietel, M.; Rabien, A.; Klauschen, F. High extracellular matrix metalloproteinase inducer/CD147 expression is strongly and independently associated with poor prognosis in colorectal cancer. Hum. Pathol. 2012, 43, 1471-1481. [CrossRef]

132. Fu, J.; Fu, J.; Chen, X.; Zhang, Y.; Gu, H.; Bai, Y. CD147 and VEGF co-expression predicts prognosis in patients with acute myeloid leukemia. Jpn. J. Clin. Oncol. 2010, 40, 1046-1052. [CrossRef] [PubMed]

(C) 2019 by the authors. Licensee MDPI, Basel, Switzerland. This article is an open access article distributed under the terms and conditions of the Creative Commons Attribution (CC BY) license (http://creativecommons.org/licenses/by/4.0/). 